\title{
Effect of Iron Application and Rhizobium Inoculation on Uptake of Nutrients in Grain and Stover of Chickpea (Cicer arietinum L.)
}

\author{
Shweta Kumari $^{1 *}$, S.K. Dubey ${ }^{1}$ and Abhinaw Kumar Singh ${ }^{2}$ \\ ${ }^{1}$ Department of Soil Science and Agricultural Chemistry CSAUA \& T, \\ Kanpur - 232104 (U.P.), India \\ ${ }^{2}$ Department of Agronomy NDUA \& T Kumarganj Faizabad - 222429 (U.P.), India \\ *Corresponding author
}

\begin{tabular}{|c|c|}
\hline & B S T R A C T \\
\hline $\begin{array}{l}\text { Ke y w o r d s } \\
\text { Chickpea, Iron, } \\
\text { Nutrient uptake, } \\
\text { Rhizobium, Stover. }\end{array}$ & \multirow{3}{*}{ 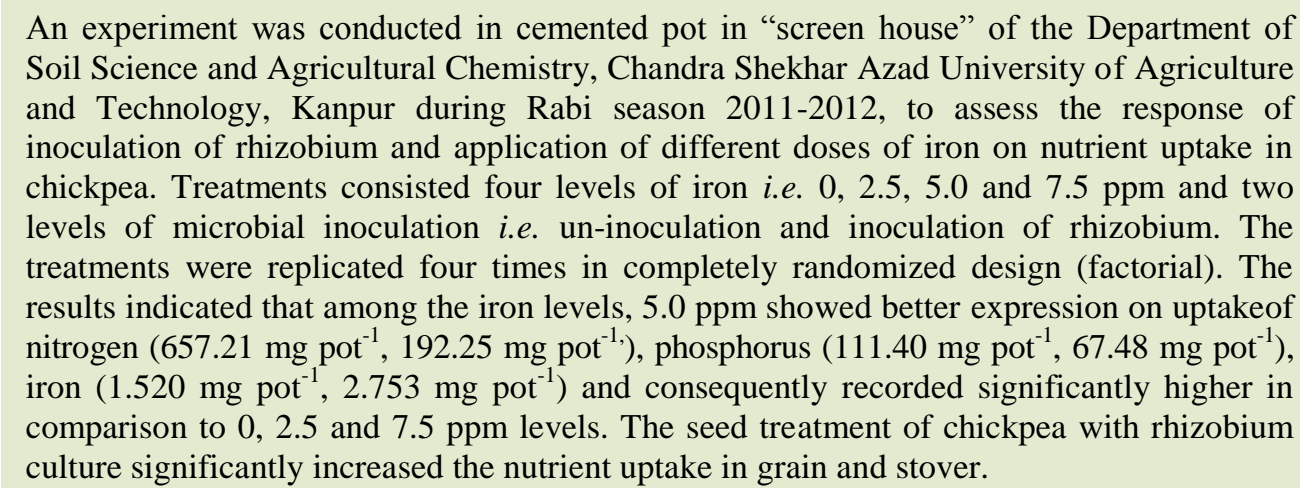 } \\
\hline Article Info & \\
\hline $\begin{array}{l}\text { Accepted: } \\
\text { 22 February } 2017 \\
\text { Available Online: } \\
\text { 10 March } 2017\end{array}$ & \\
\hline
\end{tabular}

\section{Introduction}

Chickpea (Cicer arietinum L.) is an important Rabi season pulse crop. It is a major food legume in many countries of Asia, the Middle East and South Central Americas. In India, during 2011-2012, the chickpea crop had production of about 5.89 million tonnes from an area of $7.37 \mathrm{~m}$ ha with an average productivity of $799.19 \mathrm{~kg} \mathrm{ha}^{-1}$. However, in Uttar Pradesh it is grown in $0.60 \mathrm{mha}$ with production of 0.67 million tonnes. The average productivity of Uttar Pradesh is 1120 $\mathrm{kg} \mathrm{ha}^{-1}$ (India Stat, 2012). Chickpea is grown mostly under rainfed-unirrigated conditions on low fertile soils. Generally, farmers do not apply fertilizers to chickpea crop. Under such conditions due to hungry soil the productivity of this crop is very low notably lower than the average production of this crop in other parts of the world. Therefore, this crop needs to be fertilized to get optimum economic yield.

Iron is the most critical essential micronutrient for plant growth and especially in chickpea grown at saline and alkaline soils. The saline and alkaline soils are deficient in iron which results in the chlorosis of chickpea means lack of chlorophyll which results in the synthesis of photosynthates. In deficiency of iron leaves become unable to synthesise food materials or starch as result plant may fail to 
complete its life cycle and the pod or grain formation may be affected and the pods remain empty. The application of iron in the form of $\mathrm{FeSO}_{4}$ either in soil or as aerial spray enhance the rate of photosynthesis, which results in the production of higher number of root nodules by providing sufficient food to the bacteria Rhizobium. It helps in the conversion of sufficient quantity of atmospheric $\mathrm{N}$ to nitrate $\mathrm{N}$ and facilitates in the formation of more number of pods, number of grain pod $^{-1}$ and increases seed weight $\operatorname{pod}^{-1}$ as a result higher grain yield of chickpeas may be produced. Shukla and Shukla (1994) observed that increase in $\mathrm{Fe}$ and $\mathrm{P}$ concentration in seeds of chickpea with increasing level of $\mathrm{FeSO}_{4}$ up to $50 \mathrm{~kg} /$ ha over control.

Chickpea obtains a significant proportion of its $\mathrm{N}$ requirement through symbiotic $\mathrm{N}$ fixation. Inoculation of chickpea with adequate number of rhizobia results in a significant increase in the number of nodules, nodule dry weight and $\mathrm{N}$ fixation (Sattar et $a l .$, 1993). Growth of chickpea is dependent on nodulation by effective Rhizobial strains. Mixed culture inoculation of Rhizobium with associate $\mathrm{N}$ fixing Azospirillum $s p$. and Bacillus subtilis and PSB megaterium significantly increased the total number of nodules and dry weight of nodules and consequently the grain weight of chickpea. Management practices to produce larger biomass yields under lower soils nitrate conditions may result in increased $\mathrm{N}$ fixation by chickpea (Horn et al., 1996).

The combination of Rhizobium culture and iron provides favourable condition in the formation of more number of effective root nodules in which more number of Rhizobium bacteria converts more quantity of atmospheric $\mathrm{N}$ to nitrate $\mathrm{N}$ and increases the soil fertility as a result all the growth and yield attributing components increased significantly. In this regard information available are sporadic and scarce or less work has been done hence a pot experiment project on entitled "Effect of iron and Rhizobium application on uptake of nutrients in chickpea" has been undertaken.

\section{Materials and Methods}

The experiment was carried out during Rabi season (2011-12) in screen house of the Department of Soil Science and Agricultural Chemistry, Chandra Shekhar Azad University of Agriculture and Technology, Kanpur, (U.P.) "to study the effect of iron and Rhizobium culture application on nutrient uptake on chickpea". Four levels of iron viz., 0 ppm, $2.5 \mathrm{ppm}, 5.0 \mathrm{ppm}$ and 7.5ppm and two levels of bio-fertilizers viz., un-inoculated and inoculation with Rhizobium, design in completely randomized design with four replications in cemented pots. Rhizobium inoculants were added by seed treatment. Prepared slurry of Rhizobium inoculant by adding Rhizobium culture (200 g for $10 \mathrm{~kg}$ seed) was poured on the seed and mixed with hand to get homogenous coating, thereafter dried in shade and sown the treated seed immediately. The iron was applied as ferrous chloride well mixed in Rhizobium and seed inoculation just before the sowing of chickpea crop.

Full dose of phosphorus (40 $\mathrm{kg} \mathrm{P}_{2} \mathrm{O}_{5} \mathrm{ha}^{-1}$ ) as single super phosphate was applied at the time of sowing. Ten $\mathrm{kg}$ well pulverized soil was filled in each cemented pot with polythene inner lining and five seeds were sown in each pot as per treatments on $26^{\text {th }}$ of November, 2011. Recommended cultural operations were adopted. Two plants were maintained in each pot up to the maturity and harvested on $5^{\text {th }}$ April 2012. The representative samples of grain and stover were collected for chemical analysis. Nitrogen content in grain and stover was estimated by micro Khejdahl's method as 
described by Jackson (1973). For phosphorus content wet digestion method in tri-acid mixture and estimating calorimetrically using ammonium meta-vanadate colouring reagent as described by Chapman and Pratt (1961). The iron content in grain and stover estimated with atomic absorption spectrophotometer. Total nitrogen, phosphorus and iron uptake by grain and stover were calculated by the following formula:

Uptake of nutrient $=$ Percent nutrient $\times$ Dry matter yield/100.

\section{Results and Discussion}

\section{Nitrogen (N) uptake in grain and stover}

It is visualized from the data given in table 1 that iron application and Rhizobium inoculation increased the $\mathrm{N}$ uptake in grain significantly comparison to control. However, the interaction, $\mathrm{I} \times \mathrm{Fe}$, showed non-significant effect on $\mathrm{N}$ uptake in grain. On an average, the $\mathrm{N}$ uptake increased up to the application of $5.0 \mathrm{ppm}$ Fe significantly and thereafter, decreased at $7.5 \mathrm{ppm}$ Fe. The lowest $\mathrm{N}$ uptake of 476.97 and highest of $657.21 \mathrm{mg} \mathrm{pot}^{-1}$ was recorded at control and $5.0 \mathrm{ppm} \mathrm{Fe}$, respectively. Thus, the highest uptake of $\mathrm{N}$ was 37.79 percent higher than the lowest uptake. The highest uptake of $648.24 \mathrm{mg} \mathrm{pot}^{-1}$ recorded with Rhizobium was computed 24.15 percent higher than the lowest uptake of $522.13 \mathrm{mg} \mathrm{pot}^{-1}$ recorded with un-inoculation.

It is obvious from the data given in table 2 that application of iron and seed treatment of Rhizobium culture significantly influenced N uptake, while interactions between the treatments were absent. The nitrogen uptake in chickpea increased up to $5.0 \mathrm{ppm} \mathrm{Fe}$ and thereafter, decreased at $7.5 \mathrm{ppm} \mathrm{Fe}$. On an average, the $\mathrm{N}$ uptake of $192.25 \mathrm{mg}$ pot $^{-1}$ was recorded with $5.0 \mathrm{ppm}$ Fe which was calculated 30.84 per cent higher than the lowest $\mathrm{N}$ uptake of $146.93 \mathrm{mg} \mathrm{pot}^{-1}$ at control. The highest $\mathrm{N}$ uptake $191.04 \mathrm{mg} \operatorname{pot}^{-1}$ recorded with inoculation was found 22.25 per cent higher than the $\mathrm{N}$ uptake of 156.27 mg $\operatorname{pot}^{-1}$ with un-inoculation.

This shows the synergistic effect of iron application on nitrogen and iron concentration in both grain and stover. The increase in iron concentration with its increasing doses is not questionable as iron addition in available form increased its availability to the crop. Increase in nitrogen and iron concentration due to iron application earlier also reported by Mehrotra et al., (1990) and Ghasemi-Fasaei et al., (2007).

\section{Phosphorus (P) uptake in grain and stover}

The data on $\mathrm{P}$ uptake in grain as influenced by iron application have been given in table 3 . At a glance over the table, it is obvious that $\mathrm{P}$ uptake in grain increased with an increase in iron level up to $5.0 \mathrm{ppm}$ and thereafter, decreased at $7.5 \mathrm{ppm}$. On an average, the highest of $111.40 \mathrm{mg}^{-1}$ pot $^{-1}$ recorded at $5.0 \mathrm{ppm}$ was found 22.61 per cent higher than the lowest P uptake of $90.86 \mathrm{mg} \mathrm{pot}^{-1}$ at control i.e. no iron application. Likewise iron application, Rhizobium inoculation of seeds also exhibited significant positive effect on $\mathrm{P}$ uptake in grain. On an average, the $\mathrm{P}$ uptake of $121.10 \mathrm{mg} \mathrm{pot}^{-1}$ recorded with inoculation was found 45.15 percent higher than the $\mathrm{P}$ uptake of $83.43 \mathrm{mg} \mathrm{pot}^{-1}$ with un-inoculation. The interaction, I $\times \mathrm{Fe}$, did have nonsignificant effect on $\mathrm{P}$ uptake in grain.

It is visualized from the data given in table 4 that iron application enhanced the phosphorus uptake in stover significantly up to $5.0 \mathrm{ppm}$ $\mathrm{Fe}$ and thereafter, decreased significantly at $7.5 \mathrm{ppm}$ Fe. 
Table.1 Effect of iron and Rhizobium on nitrogen uptake $\left(\mathrm{mg} \mathrm{pot}^{-1}\right)$ in grain of chickpea

\begin{tabular}{|c|c|c|c|}
\hline Treatment & Uninoc. & Inoc. & Mean \\
\hline 0 ppm Fe & 435.18 & 518.75 & $\mathbf{4 7 6 . 9 7}$ \\
\hline $\mathbf{2 . 5} \mathbf{~ p p m ~ F e ~}$ & 517.08 & 622.08 & $\mathbf{5 6 9 . 5 8}$ \\
\hline $\mathbf{5 . 0} \mathbf{~ p p m ~ F e}$ & 581.44 & 732.98 & $\mathbf{6 5 7 . 2 1}$ \\
\hline $\mathbf{7 . 5} \mathbf{~ p p m ~ F e}$ & 554.81 & 719.16 & $\mathbf{6 3 6 . 9 9}$ \\
\hline Mean & $\mathbf{5 2 2 . 1 3}$ & $\mathbf{6 4 8 . 2 4}$ & \\
\hline IE(d) \pm & 39.43 & $\mathbf{F e}$ & $\mathbf{I} \times \mathbf{F e}$ \\
\hline CD at 5 \% & 81.38 & 56.29 & 79.10 \\
\hline
\end{tabular}

Table.2 Effect of iron and Rhizobium on nitrogen uptake $\left(\mathrm{mg} \mathrm{pot}^{-1}\right)$ in stover of chickpea

\begin{tabular}{|c|c|c|c|}
\hline Treatment & Uninoc. & Inoc. & Mean \\
\hline 0 ppm Fe & 134.98 & 158.88 & $\mathbf{1 4 6 . 9 3}$ \\
\hline $\mathbf{2 . 5} \mathbf{~ p p m ~ F e ~}$ & 155.39 & 185.47 & $\mathbf{1 7 0 . 4 3}$ \\
\hline $\mathbf{5 . 0} \mathbf{~ p p m ~ F e}$ & 172.14 & 212.36 & $\mathbf{1 9 2 . 2 5}$ \\
\hline $\mathbf{7 . 5} \mathbf{~ p p m ~ F e}$ & 162.58 & 207.44 & $\mathbf{1 8 5 . 0 1}$ \\
\hline Mean & $\mathbf{1 5 6 . 2 7}$ & $\mathbf{1 9 1 . 0 4}$ & $\mathbf{I} \times \mathbf{F e}$ \\
\hline SE(d) \pm & $\mathbf{I}$ & $\mathbf{F e}$ & 9.13 \\
\hline CD at 5 \% & 11.42 & 7.21 & N.S. \\
\hline
\end{tabular}

Table.3 Effect of iron and Rhizobium on phosphorus uptake $\left(\mathrm{mg} \mathrm{pot}^{-1}\right)$ in grain of chickpea

\begin{tabular}{|c|c|c|c|}
\hline Treatment & Uninoc. & Inoc. & Mean \\
\hline 0 ppm Fe & 75.80 & 105.92 & $\mathbf{9 0 . 8 6}$ \\
\hline $\mathbf{2 . 5} \mathbf{~ p p m ~ F e ~}$ & 84.25 & 120.38 & $\mathbf{1 0 2 . 3 2}$ \\
\hline $\mathbf{5 . 0} \mathbf{~ p p m ~ F e ~}$ & 89.76 & 133.03 & $\mathbf{1 1 1 . 4 0}$ \\
\hline $\mathbf{7 . 5} \mathbf{~ p p m ~ F e}$ & 83.91 & 125.05 & $\mathbf{1 0 4 . 4 8}$ \\
\hline Mean & $\mathbf{8 3 . 4 3}$ & $\mathbf{1 2 1 . 1 0}$ & I $\times$ Fe \\
\hline I $(\mathbf{d}) \pm$ & 8.43 & Fe & 16.20 \\
\hline CD at 5 \% & 17.40 & 12.16 & N.S. \\
\hline
\end{tabular}


Table.4 Effect of iron and Rhizobium on phosphorus uptake $\left(\mathrm{mg} \mathrm{pot}^{-1}\right)$ in stover of chickpea

\begin{tabular}{|c|c|c|c|}
\hline Treatment & Uninoc. & Inoc. & Mean \\
\hline 0 ppm Fe & 49.79 & 57.23 & $\mathbf{5 3 . 5 1}$ \\
\hline $\mathbf{2 . 5} \mathbf{~ p p m ~ F e ~}$ & 55.75 & 65.43 & $\mathbf{6 0 . 5 9}$ \\
\hline $\mathbf{5 . 0} \mathbf{~ p p m ~ F e}$ & 60.92 & 74.03 & $\mathbf{6 7 . 4 8}$ \\
\hline $\mathbf{7 . 5} \mathbf{~ p p m ~ F e}$ & 57.26 & 71.96 & $\mathbf{6 4 . 6 1}$ \\
\hline Mean & $\mathbf{5 5 . 9 3}$ & $\mathbf{6 7 . 1 6}$ & $\mathbf{I} \times \mathbf{F e}$ \\
\hline SE(d) \pm & $\mathbf{I}$ & $\mathbf{F e}$ & 8.24 \\
\hline CD at 5 \% & 4.26 & 6.29 & N.S. \\
\hline
\end{tabular}

Table.5 Effect of iron and Rhizobium on iron uptake $\left(\mathrm{mg} \mathrm{pot}^{-1}\right)$ in grain of chickpea

\begin{tabular}{|c|c|c|c|}
\hline Treatment & Uninoc. & Inoc. & Mean \\
\hline 0 ppm Fe & 0.810 & 1.074 & $\mathbf{0 . 9 4 2}$ \\
\hline $\mathbf{2 . 5} \mathbf{~ p p m ~ F e ~}$ & 1.053 & 1.446 & $\mathbf{1 . 2 5 0}$ \\
\hline $\mathbf{5 . 0} \mathbf{~ p p m ~ F e}$ & 1.257 & 1.783 & $\mathbf{1 . 5 2 0}$ \\
\hline $\mathbf{7 . 5} \mathbf{p p m ~ F e}$ & 1.211 & 1.769 & $\mathbf{1 . 4 9 0}$ \\
\hline Mean & $\mathbf{1 . 0 8 3}$ & $\mathbf{1 . 5 1 8}$ & $\mathbf{I} \times \mathbf{F e}$ \\
\hline $\mathbf{I}(\mathbf{I}) \pm$ & 0.0006 & $\mathbf{F e}$ & 0.0012 \\
\hline CD at 5 \% & 0.0012 & 0.0009 & N.S. \\
\hline
\end{tabular}

Table.6 Effect of iron and Rhizobium on iron uptake $\left(\mathrm{mg} \mathrm{pot}^{-1}\right)$ in stover of chickpea

\begin{tabular}{|c|c|c|c|}
\hline Treatment & Uninoc. & Inoc. & Mean \\
\hline 0 ppm Fe & 1.492 & 1.950 & $\mathbf{1 . 7 2 1}$ \\
\hline $\mathbf{2 . 5} \mathbf{~ p p m ~ F e ~}$ & 1.964 & 2.601 & $\mathbf{2 . 2 8 3}$ \\
\hline $\mathbf{5 . 0} \mathbf{~ p p m ~ F e}$ & 2.268 & 3.238 & $\mathbf{2 . 7 5 3}$ \\
\hline $\mathbf{7 . 5} \mathbf{~ p p m ~ F e}$ & 2.173 & 3.205 & $\mathbf{2 . 6 8 9}$ \\
\hline Mean & $\mathbf{1 . 9 7 4}$ & $\mathbf{2 . 7 4 9}$ & $\mathbf{I} \times \mathbf{F e}$ \\
\hline SE(d) \pm & $\mathbf{I}$ & $\mathbf{F e}$ & 0.0028 \\
\hline CD at 5 \% & 0.0014 & 0.0020 & N.S. \\
\hline
\end{tabular}


On an average, the phosphorus uptake of $67.48 \mathrm{mg} \mathrm{pot}^{-1}$ recorded at $5.0 \mathrm{ppm}$ Fe was computed 26.11 percent higher than the phosphorus uptake of $53.51 \mathrm{mg} \mathrm{pot}^{-1}$ recorded with $0 \mathrm{ppm} \mathrm{Fe}$ (control). It is also apparent from the data that Rhizobium treatment of seeds enhanced the accumulation of phosphorus in stover significantly in comparison to un-inoculation (Table 4). On an average, the phosphorus uptake of 67.16 $\mathrm{mg} \mathrm{pot}^{-1}$ recorded with inoculation was found 20.08 percent higher than the phosphorus uptake of $55.93 \mathrm{mg}$ pot $^{-1}$ recorded with uninoculation. The interaction of iron levels and Rhizobium inoculation did not have significant effect on phosphorus uptake in stover.

The iron application has the antagonistic effect on the availability of phosphorus in the soil. Yadav et al., (2002) observed depressing effect of iron on content and uptake of phosphorus on mungbean crop. These present findings are also supported by the results of Singh et al., (1993).

\section{Iron uptake in grain and stover}

The data on iron uptake in grain as influenced by iron levels and Rhizobium inoculation have been illustrated in table 5. However, interaction between the iron level and Rhizobium inoculation did not affect iron uptake in grain. Likewise, nitrogen and phosphorus uptake, iron uptake also increased with increase in iron level up to $5.0 \mathrm{ppm} \mathrm{Fe}$ and thereafter, decreased at $7.5 \mathrm{ppm}$ Fe level. On an average, the iron uptake of $1.520 \mathrm{mg}$ pot $^{-1}$ recorded with $5.0 \mathrm{ppm}$ Fe was computed 61.36 percent higher than the iron uptake of $0.942 \mathrm{mg} \mathrm{pot}^{-1}$ recorded with control (0 ppm $\mathrm{Fe})$.

The Rhizobium inoculation had significant positive effect on iron uptake in grain in comparison to un-inoculation. On an average, the iron uptake of $1.518 \mathrm{mg} \mathrm{pot}^{-1}$ recorded with inoculation was found 40.17 percent higher than the iron uptake of $1.083 \mathrm{mg} \mathrm{pot}^{-1}$ obtained with un-inoculation, Kantar et al., (2003).

The relevant data on iron uptake in stover as influenced by application of graded doses of iron and Rhizobium treatment of seeds has been given in table 6 . The interaction, $\mathrm{I} \times \mathrm{Fe}$, had not significant effect on iron uptake in stover. It is quite obvious from the data that iron application showed significant positive effect on iron uptake in stover also. It increased up to $5.0 \mathrm{ppm} \mathrm{Fe}$ and thereafter, decreased at $7.5 \mathrm{ppm}$ Fe level. On an average, the iron uptake of $2.753 \mathrm{mg} \mathrm{pot}^{-1}$ recorded at $5.0 \mathrm{ppm}$ Fe was found 59.97 per cent higher than the iron uptake of $1.721 \mathrm{mg} \mathrm{pot}^{-1}$ recorded with no iron application (control). The Rhizobium treatment of seeds also exhibited significant positive effect on iron uptake in stover in comparison to uninoculation (Table 6). On an average, the iron uptake of $2.749 \mathrm{mg}$ pot $^{-1}$ recorded with inoculation was computed 39.26 per cent higher than the iron uptake of $1.974 \mathrm{mg} \mathrm{pot}^{-1}$ recorded with un-inoculation. The treatment of seeds with Rhizobium culture had significant positive effect on content and uptake of nitrogen, phosphorus and iron in both grain and stover in comparison to uninoculation. The Rhizobium inoculation of seeds resulted in higher nitrogen fixation and nitrogen has positive relationship with nitrogen, phosphorus and iron. Therefore, in the present study, the concentration of nitrogen, phosphorus and iron and their uptake increased significantly with Rhizobium inoculation in comparison to un-inoculation. These results are concordantly supported by the findings of Mahmud et al., (1997) and Raghuwanshi et al., (2003).

From the results narrated above, it could be concluded that application of $5.0 \mathrm{ppm}$ Fe and Rhizobium inoculation of seeds is increased the nutrient uptake in chickpea. 


\section{References}

Chapman, H.D. and Pratt, F. 1961. Methods of analysis for soils, plant and water. University of California, U.S.A., 309.

Ghasemi-Fasaei, R., Ronaghi, A., Maftoun, M., Karimian, N.A. and Soltanpour, P.N. 2007. Iron-manganese interaction in chickpea as affected by foliar and soil application of iron in a calcareous soil. Communications in Soil Sci. Plant Analysis, 36(13/14): 1717-1725.

Horn, C.P., Dalal, R.C., Birch, C.J. and Doughton, J.A. 1996. Sowing time and tillage practice affect chickpea yield and nitrogen fixation. Nitrogen accumulation, nitrogen fixation and soil nitrogen balance. Australian $J$. Experimental Agri., 36(6): 701-706.

India Stat. $2011-12$.

Jackson, M.L. 1973. Soil chemical analysis. Prentice Hall of India (Pvt.) Ltd., New Delhi.

Kantar, F., Elkoca, E., Ogutcu, H. and Algur, O.F. 2003. Chickpea yields in relation to Rhizobium inoculation from wild chickpea at high altitudes. J. Agronomy and Crop Sci., 189(5): 291-297.

Mahmud, M.S., Salaiman, A.R.M., Hoque, M.S. and Hashem, M.A. 1997. Influence of Rhizobium inoculants and nitrogen on nodulation, growth and nitrogen uptake of lentil. Annals of Bangladesh Agri., 7(2): 139-143.

Mehrotra, S.C., Sharma, C.P. and Agarwala, S.C. 1990. Iron-phosphorus interaction in chickpea genotypes that differ in tolerance to iron-stress. Proceedings of the International Congress of Plant Physiology, 2: 1146-1150.

Raghuwanshi, K.S., Patil, J.D. and Sawant, D.M. 2003. Response of chickpea to Rhizobium strains under dryland conditions. J. Maharashtra Agri. Univ., 28(2): 207-208.

Sattar, M.A., Quadar, M.A. and Danso, S.K.A. 1993. Nodulation nitrogen fixation and yield of chickpea as influenced by host cultivar and BradyRhizobium strain differences. Soil Biol. Biochem., 27(4/5): 725-727.

Shukla, V. and Shulka, I.C. 1994. Effect of $\mathrm{Fe}, \mathrm{Mo}, \mathrm{Zn}$ and $\mathrm{P}$ on symbiotic nitrogen fixation of chickpea. Indian J. Agri. Chem., 32: 118-123.

Singh, V. Singh, R.P. and Khan, Nizamuddin. 1993. Effect of $\mathrm{P}$ and Fe application on the yield and nutrient contents in chickpea. J. Indian Society of Soil Sci., 41(1): 186-187.

Yadav, P.S., Kameriya, P.R. and Rathore, S. 2002. Effect of $P$ and Fe fertilization on yield, content and nutrient uptake in mungbean on loamy sand soil. J. Indian Society of Soil Sci., 50(2): 225-226.

\section{How to cite this article:}

Shweta Kumari, S.K. Dubey and Abhinaw Kumar Singh. 2017. Effect of Iron Application and Rhizobium Inoculation on Uptake of Nutrients in Grain and Stover of Chickpea (Cicer arietinum L.). Int.J.Curr.Microbiol.App.Sci. 6(3): 1437-1443.

doi: https://doi.org/10.20546/ijcmas.2017.603.163 